\title{
ANALISIS PENGARUH JENIS BBM TERHADAP KONSUMSI BBM KENDARAAN PENUMPANG 1200 CC DI LALU LINTAS TOL SEMARANG
}

\author{
Haris Kurnia Sandi*, Tabah Priangkoso, Darmanto \\ Jurusan Teknik Mesin Fakultas Teknik Universitas Wahid Hasyim Semarang \\ Jln. Menoreh tengah X/22 Sampangan, Semarang, Indonesia \\ *Email: hariskurniasandi12345@gmail.com
}

\begin{abstract}
Motor bakar merupakan mesin kalor yang menggunakan energi panas untuk melakukan kerja mekanis atau mengubah energi panas menjadi tenaga mekanis. Motor bakar itu memerlukan bahan bakar yang sesuai mesin itu sendiri agar bekerja dengan baik dan menghasilkan tenaga yang optimal, maka perlu meneliti tentang pengaruh konsumsi BBM kendaraan penumpang terhadap lalu lintas di jalan tol Semarang. Tujuan penelitian ini adalah untuk mengetahui bagaimana pengaruh konsumsi BBM kendaraan penumpang terhadap lalu lintas di jalan tol Semarang. Dari hasil analisis bahwa semua bahan bakar yang menggunakan gigi tertinggi akan lebih hemat bahan bakarnya pada kendaraan penumpang dan konsumsi bahan bakar yang paling hemat adalah Pertamax pada semua kecepatan bisa menempuh jarak 18,42 km/L sedangkan yang paling boros yaitu Pertalite cuma menempuh jarak 17,2 km/L.
\end{abstract}

Kata kunci: bahan bakar, kendaraan penumpang, konsumsi, motor bakar.

\section{PENDAHULUAN}

Motor bakar merupakan mesin kalor yang menggunakan energi panas untuk mengubah energi kimia dari bahan bakar menjadi energi panas (termal) akan menghasilkan energi mekanik (gerak). Terjadi energi panas karena adanya pembakaran di ruang bakar yaitu bahan bakar dengan udara dan sistem percikan api dari busi di dalam mesin itu sendiri. Motor bakar itu memerlukan jenis bahan bensin yang sesuai desain mesin itu sendiri agar bekerja dengan baik dan menghasilkan tenaga yang optimal (Sinaga dkk., 2011). Pada umumnya semakin tinggi oktan, maka semakin mahal harga bensin. Namun belum tentu kalau kita mengisi bensin beroktana tinggi pada motor bakar akan menghasilkan tenaga yang optimal. Bahwa setiap jenis motor bakar mempunyai spesifikasi mesin dan bahan bakar yang berbeda-beda. Pada saat ini banyak masalah yang timbul pada motor bakar karena menggunakan bahan bakar sesuai keinginan yang tidak sesuai dengan prosedur dalam spesifikasi motor bakar itu sendiri sehingga motor bakar tidak bisa menghasilkan tenaga yang maksimal (Sinaga dkk., 2013). Tujuan dari penelitian ini adalah untuk mengetahui bagaimana pengaruh konsumsi BBM kendaraan penumpang $1200 \mathrm{CC}$ pada lalu lintas di jalan tol.
Bahan bakar adalah bahan yang apabila dibakar dapat meneruskan pembakarannya dengan sendirinya serta mengeluarkan kalor (panas). Berdasarkan bentuknya ada 3 jenis bahan bakar yaitu bahan bakar padat, bahan bakar cair dan bahan bakar gas

Pertalite adalah bahan bakar minyak yang mempunyai research octane number (RON) 90. Pertalite dihasilkan dengan penambahan zat aditif dalam proses pengolahannya di kilang minyak. Keunggulan Pertalite adalah membuat tarikan mesin kendaraan menjadi lebih ringan. Zat adiktif yang diberikan pada BBM Pertalite yang membuat kualitasnya ada di atas Premium dan bersaing dengan Pertamax. Pertalite, berwarna hijau terang sebagai dampak pencampuran bahan Premium dengan Pertamax (M K Jannah, 2014).

Pertamax (RON 92), Pertamax ditujukan untuk kendaraan yang mensyaratkan penggunaan bahan bakar beroktana tinggi tanpa timbel (unleaded). Pertamax juga direkomendasikan untuk kendaraan yang diproduksi diatas tahun 1990, terutama yang telah menggunakan teknologi setara dengan electronic fuel injection. Keunggulan Pertamax yaitu bebas timbal, oktan lebih tinggi dari pada premium dan Pertalite, bisa menerima tekanan mesin kompresi tinggi karena Pertamax memiliki oktan yang tinggi 
Pertamax Turbo merupakan bahan bakar untuk kendaraan mesin bensin yang merupakan hasil improvement teknologi yang memiliki research octane number $(\mathrm{RON}) 98$. Berwarna likuid merah serta dilengkapi ignition boost formula (IBF), Pertamax Turbo didesain untuk mesin yang memiliki kompresi minimum 12:1 atau menggunakan Teknologi turbo charger. Keunggulan Pertamax Turbo yaitu kendaraan lebih responsif, akselerasi lebih sempurna, bisa mendukung kecepatan maksimal.

Perkembangan teknologi otomotif hingga saat ini diupayakan untuk mengatasi berbagai permasalahan yang timbul akibat pengoperasian kendaraan. Beberapa permasalahan yang timbul dari pengoperasian kendaraan di antaranya peningkatan pencemaran udara yang disebabkan oleh emisi gas buang. Peningkatan jumlah kecelakaan lalu lintas karena pengoperasian kendaraan. Peningkatan jumlah kebutuhan bahan bakar karena pertumbuhan kendaraan semakin meningkat. Perbaikan kualitas bahan bakar dan perbaikan teknologi kendaraan bermotor baik terhadap motor penggerak maupun sistem kendali yang terdapat pada kendaraan. Emisi gas buang kendaraan pembaruan konstruksi mesin, teknologi mobil listrik (electric vehicle), hybrid engine, teknologi fuel cell, kelengkapan alat keselamatan pada kendaraan dan cara mengemudi yang baik (Sinaga dkk., 2013)

\section{METODE PENELITIAN}

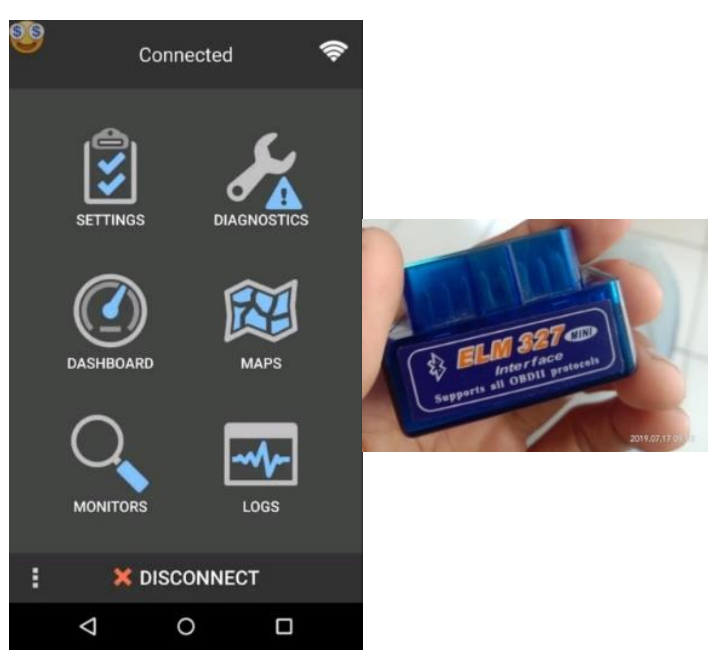

Gambar 1. scanner OBD II
Alat yang di gunakan dalam penelitian ini adalah engine scanner OBD II (ELM 327 mini). Device ini di gunakan untuk mengetahui konsumsi bahan bakar pada mobil. Alat ini dihubungkan ke mobil melalui soket OBD II yang terdapat di bawah dashboard yang menggunakan Android melalui bluetooth. Selanjutnya smartphone Android digunakan sebagai alat untuk menginstal aplikasi OBD II yang dihubungkan dengan OBD II melalui bluetooth. Aplikasi dalam penelitian ini digunakan untuk merekam data dari scanner OBD II ELM 327 yang dihubungkan ke smartphone melalui bluetooth.

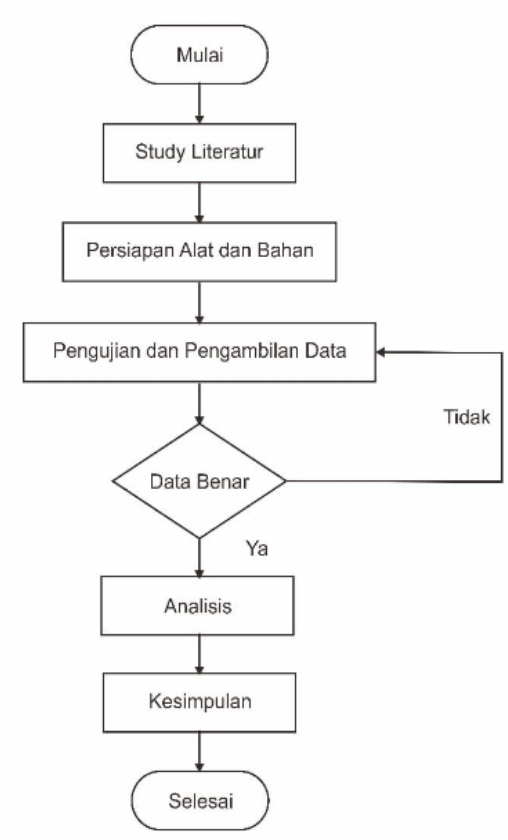

Gambar 2. Flowchart penelitian

Dalam rancangan penelitian ini dalam bentuk flowchart untuk menyelesaikan pengaruh bahan bakar Pertalite, Pertamax dan Pertamax Turbo terhadap konsumsi bahan bakar kendaraan penumpang dapat diselesaikan seperti pada Gambar 3.1.

\section{HASIL DAN PEMBAHASAN}

Hasil pengujian bahwa semua bahan bakar yang menggunakan posisi gigi yang tinggi akan menghemat konsumsi bahan bakarnya. Dijelaskan untuk gigi yang lebih tinggi hemat dibandingkan gigi yang lebih rendah sedangkan gigi 3 lebih boros dibandingkan gigi 2 disebabkan karena faktor 
jalan naik sehingga akselerasi tinggi maka konsumsi bahan bakarnya lebih banyak. Dapat dilihat gambar 1, 2 dan 3.

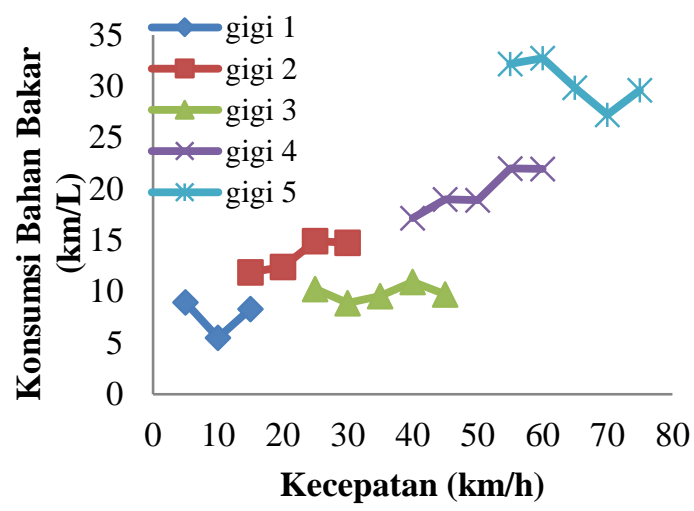

Gambar 3. Konsumsi bahan bakar Pertalite

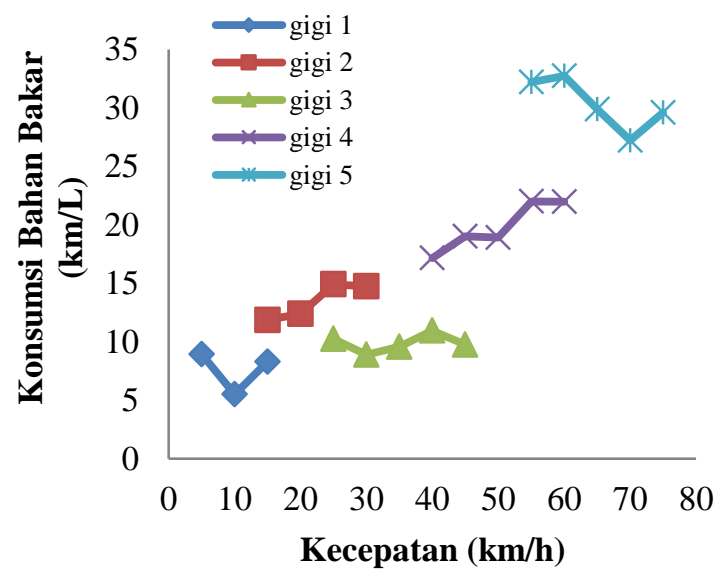

Gambar 4. konsumsi bahan bakar Pertamax

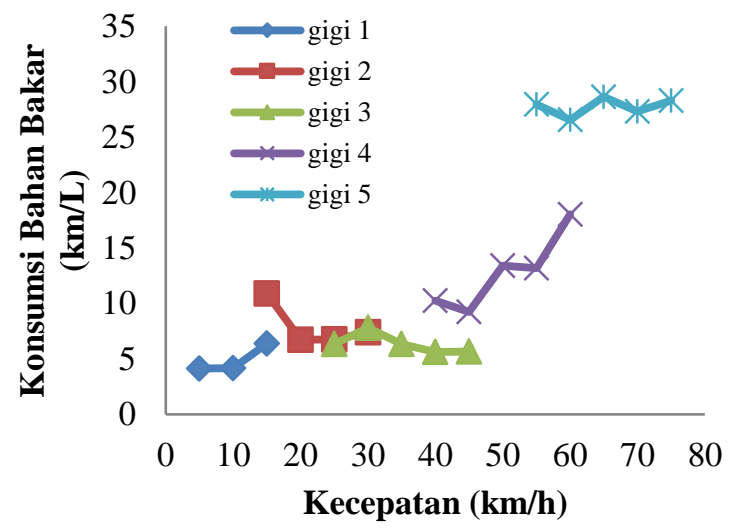

Gambar 5. konsumsi bahan bakar Pertamax Turbo
Untuk jenis bahan bakar itu sangat berpengaruh pada kendaraan penumpang. Bahan bakar Pertalite adalah yang paling boros sedangkan Pertamax merupakan jenis bahan bakar yang paling irit untuk semua rata-rata posisi gigi dan kecepatan yang sama, dapat di lihat pada gambar 4,5,6,7dan 8 .

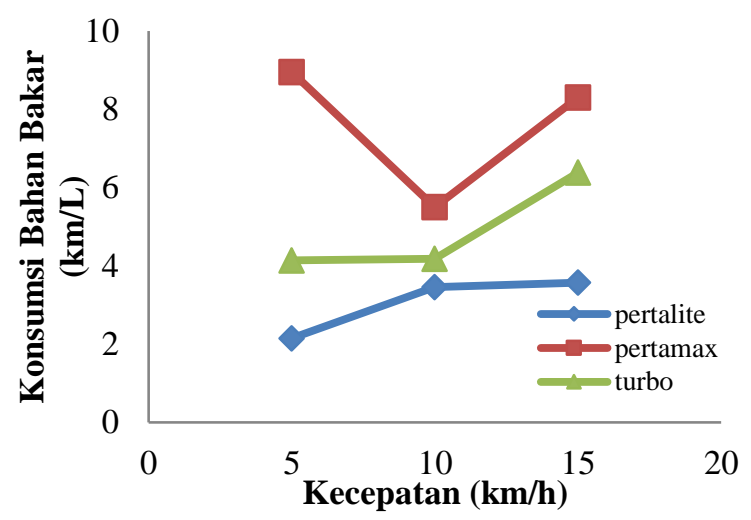

Gambar 6. konsumsi bahan bakar gigi 1

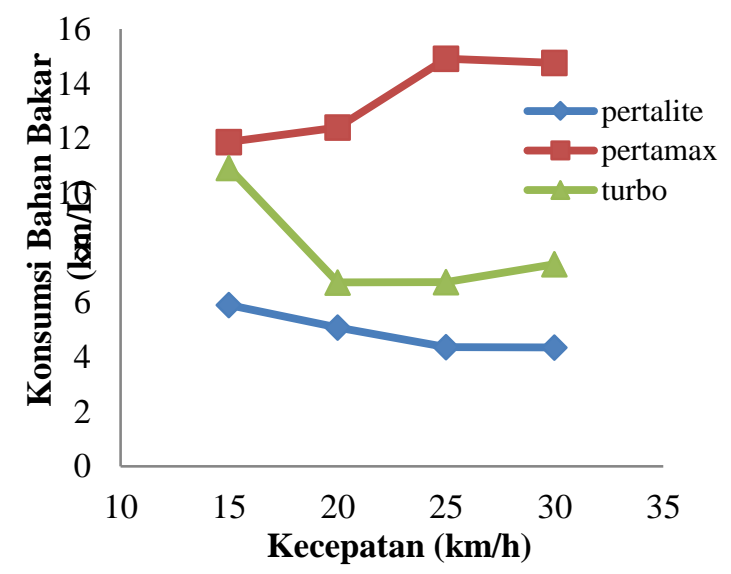

Gambar 7. Konsumsi bahan bakar gigi 2

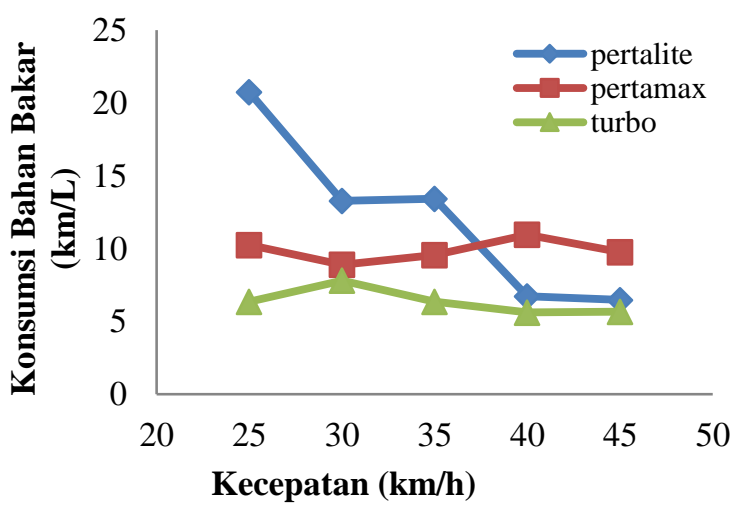

Gambar 8. Konsumsi bahan bakar gigi 3 


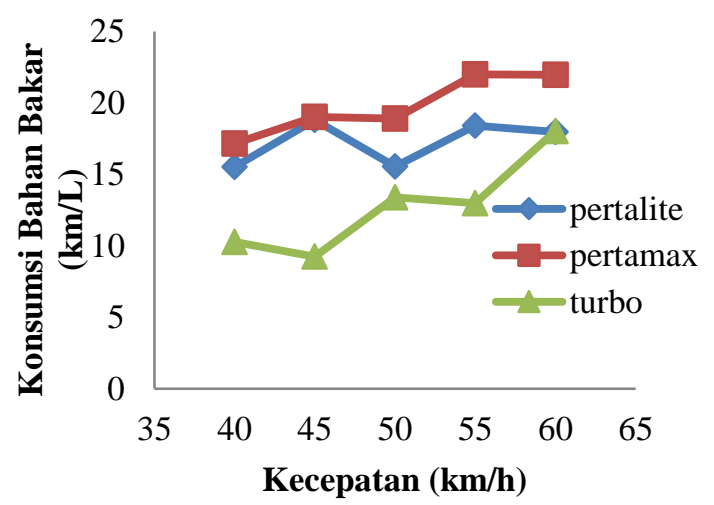

Gambar 9. Konsumsi bahan bakar gigi 4

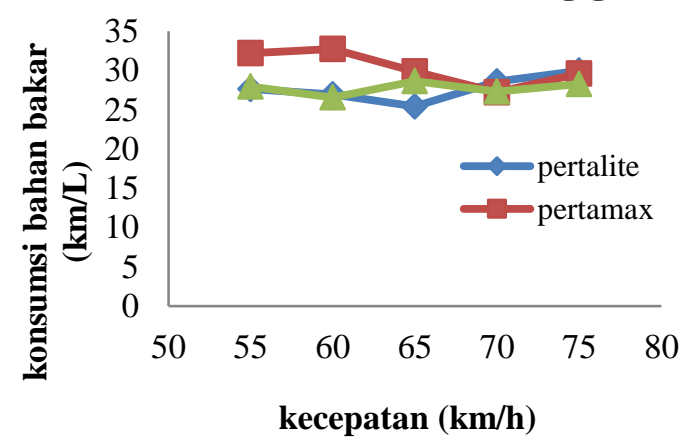

Gambar 10. Konsumsi bahan bakar gigi 5

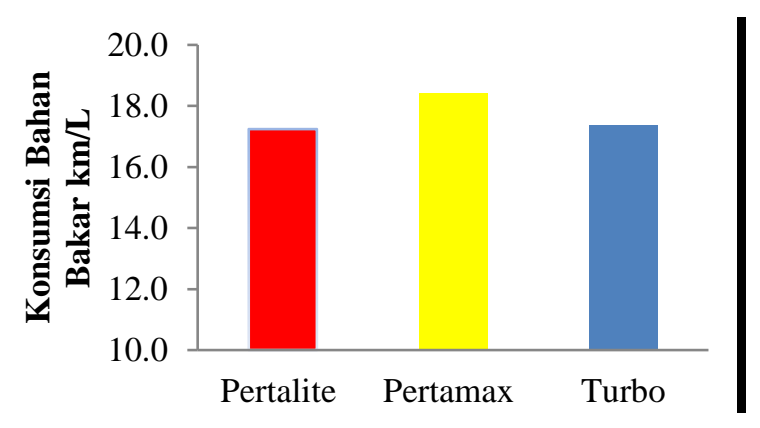

Gambar 11. Rata - rata konsumsi bahan bakar

Konsumsi bahan bakar yang paling boros pada bahan bakar Pertalite menempuh jarak $17,2 \mathrm{~km} / \mathrm{L}$ dan yang paling irit konsumsi bahan bakar pada bahan bakar Pertamax menempuh jarak $18,42 \mathrm{~km} / \mathrm{L}$, dapat di lihat pada gambar 9 .

\section{PENUTUP}

Kesimpulan

Hasil analisis pengaruh BBM terhadap konsumsi bahan bakar mobil penumpang 1200 $\mathrm{CC}$ di lalu lintas tol Semarang dengan bahan bakar Pertalite, Pertamax, dan Pertamax Turbo dapat disimpulkan bahwa penggunaan gigi yang lebih tinggi akan lebih hemat konsumsi bahan bakarnya dibandingkan gigi yang lebih rendah pada kendaraan penumpang .

Jenis bahan bakar berpengaruh terhadap konsumsi bahan bakar kendaraan penumpang. Bahan bakar jenis Pertalite menjadi bahan bakar yang paling boros sedangkan bahan bakar Pertamax yang paling irit untuk kecepatan dan posisi gigi yang sama. Untuk bahan bakar rata-rata yang paling hemat yaitu bahan bakar Pertamax bisa menempuh jarak $18,42 \mathrm{Km} / \mathrm{L}$ sedangkan bahan bakar yang paling boros yaitu bahan bakar Pertalite cuma bisa menempuh jarak 17,2 Km/L.

\section{DAFTAR PUSTAKA}

M K Jannah. (2014). Pertalite Versus Premium-Studi Tentang Berbagai Tipe Bahan Bakar Terhadap Prestasi Mesin Mobil Toyota. www.okezone.com

Sinaga, N., Priangkoso, T., WIDAYANA, D., \& $\quad$... (2011). Kaji eksperimental pengaruh beberapa parameter berkendaraan terhadap tingkat konsumsi bahan bakar kendaraan penumpang kapasitas silinder 1500-2000 cc. eprints.undip.ac.id.

http://eprints.undip.ac.id/76474/

Sinaga, N., Purnomo, S. J., \& Dewangga, A. (2013). Pengembangan model persamaan konsumsi bahan bakar efisien untuk mobil penumpang berbahan bakar bensin sistem injeksi elektronik (efi). eprints.undip.ac.id.

http://eprints.undip.ac.id/75837/ 